\title{
College English Teaching Reform from the Perspective of Implementation of Course Teaching with Ideological \& Political Education Under the Belt and Road Initiative
}

\author{
*Bing $\mathrm{He}$
}

\author{
School of foreign language, Dalian Jiaotong University, DaLian, China \\ *Corresponding author e-mail: rachelhe2008@163.com
}

\begin{abstract}
College students are the future of our country and shoulder the heavy responsibility of history. Under the background of the extensive policy of "one belt and one road", the state needs colleges and universities to cultivate compound talents that are suitable for the national development strategy. At the same time, we should also see that the rapid development of economic globalization in the 21 st century, the complexity of the international situation, and the diversity of values and ideas lead to the confusion of some college students' beliefs and ideals, the lack of ideological quality, and the bad moral consciousness. In order to create a new situation for the development of higher education in our country, we should take moral education as the central link, run ideological and political work through the whole process of education and teaching in order to realize the whole process and all-round education. As an independent discipline, College English has its distinctive characteristics. It needs to open up education and teaching ideas, innovate teaching methods, expand education and teaching channels, integrate ideological and political education with English teaching, and integrate the development of "one belt and one road" into College English classroom teaching, and design reasonable teaching plans in College English education. Only in this way can we train the compound talents to adapt to the new era and to realize the quality of College English teaching and the education of College Students' comprehensive quality and ideological quality.
\end{abstract}

Keywords: along the way, College English teaching, curriculum thinking, teaching design practice

\section{INTRODUCTION}

During his visit to Central Asia and Southeast Asian countries in 2013, President Xi Jinping proposed to build the "Silk Road Economic Belt" and "the maritime Silk Road in twenty-first Century", that is, the "one belt and one road" initiative. The key to the construction of "one belt and one road" is interconnection, including policy communication, facilities interconnection, smooth trade, financing and common people's hearts. Combined with the historical opportunity of "one belt and one road", through investigating the market demand, we should clarify the goal of personnel training, deepen the reform of teaching mode, attach importance to the cultivation of students' innovative consciousness and entrepreneurial ability, and enhance the employability and competitiveness of graduates, so that students can have both professional knowledge and ability to communicate with foreign languages, and at the same time have the quality of innovation and entrepreneurship. With the continuous development of society, the needs of society cannot be met only througn the ideological and political courses to make corresponding measures. College education should teach students according to their aptitude, combine teaching materials with the development of the real society, integrate the theory of Ideological and political education into the classroom to deepen students' understanding, and make students become talents with cultural quality, moral quality and all-round development. "Ideological and political education in curriculum" is a new teaching theory and a new teaching system including ideological and political education objectives. Among them, curriculum is the carrier of Ideological and political education, and ideological and political education is the soul of curriculum. It is also a cultural product under the background of diversified society. It aims to influence the students' world outlook, outlook on life and values through the teaching process of Marxist theory and socialist core values. In addition, the ideological and political education resources of the subject can be further explored to promote the continuous improvement of the course so as to realize the Course Association Advance together.

According to the spirit of the national medium and long term education reform and development plan (2010-202) and the Ministry of education's opinions on comprehensively improving the quality of higher education and other documents, the College English 
teaching guide puts forward that learning English can directly understand foreign advanced management experience and ideas, learn and understand the world's excellent culture and civilization, and spread China at the same time Culture promotes extensive exchanges between our country and people of all countries. In 2018, the national education conference pointed out that to integrate morality education, culture and knowledge education, social practice education, discipline system, teaching system, teaching material system and management system should be designed around this goal. In 2019, the National Symposium of Ideological and political theory teachers made it clear that the reform and innovation of Ideological and political theory curriculum should adhere to the unity of explicit education and implicit education, tap the ideological and political education resources contained in other courses and teaching methods, and realize all-round education of the whole staff. Ideological and political education runs through the whole process of education and teaching. Making good use of classroom teaching as the main channel, we should establish a "Curriculum Education" system, so as to promote all kinds of courses and ideological and political theory courses to work together in the same direction and form a joint force. At the same time, it is urgent to enhance the awareness of cross-cultural communication, cultivate high-quality, innovative and high-level management talents.

\section{BACKGROUND OF "ONE BELT AND ONE ROAD”}

The Silk Road started from ancient China and connected Asia, Africa and Europe. Its original function was to transport silk, porcelain and other commodities produced in ancient China. Later, it became the main road for economic, political and cultural exchanges between the East and the West. In terms of transportation, the silk road is mainly divided into the land Silk Road and the maritime Silk Road. With the development of the times, the Silk Road became the general designation of all political, economic and cultural exchanges between ancient China and the West.

Today's world is undergoing complex and profound changes. The deep-seated impact of the international financial crisis continues to emerge. The world economy is recovering slowly, and the development problems faced by all countries are still severe. We will build a "one belt and one road" in line with the trend of world multi-polarization, economic globalization, cultural diversification and social informatization. We must uphold the spirit of open regional cooperation and strive to safeguard the global free trade system and the open world economy. We will work together to build a "one belt and one road" effort to interconnect and interconnect the Asian and European non continental and adjacent oceans. We should establish and strengthen the partnership among all the countries along the border and build an all directional, multi-level and composite interconnection and interconnection network. In this way, we can realize the pluralistic, autonomous, balanced and sustainable development of all the countries along the route. We will enhance people to people and cultural exchanges and mutual learning among people of all countries along the line, so that people of all countries can meet, know, trust and respect each other, and share a harmonious, peaceful and prosperous life.

\section{THE CURRENT UNIVERSITY EDUCATION UNDER THE ONE BELT AND ONE ROAD INITIATIVE}

The new Silk Road University Alliance was founded on May 22, 2015, initiated by Xi'an Jiaotong University, with nearly 100 universities from 22 countries and regions successively joining. With the theme of "building a platform for educational cooperation and promoting regional open development", we will promote exchanges and cooperation among universities of countries and regions along the "New Silk Road Economic Belt" in terms of inter university exchanges, personnel training, scientific research cooperation, cultural communication, policy research, medical services, etc., enhance understanding and friendship among young people, and cultivate high-quality and complex students with international vision We will serve the development and construction along the "New Silk Road Economic Belt" and in Eurasia.

On October 17, 2015, the high-end academic seminar on cultural heritage and innovation of the Preparatory Committee of the Silk Road (Dunhuang) International Cultural Expo was held in Dunhuang. From the Fudan University, Beijing Normal University, Lanzhou University and the 46 national and international universities of Ural, Korea and Pukyong National University, a strategic alliance of "one belt and one road" has been set up in Dunhuang, Gansu, to explore new talents training system for transnational training and cross border mobility, and to train high-quality talents with international vision. We should promote the comprehensive exchanges and cooperation among universities and universities in the areas along the "one belt and one way" in the fields of education, science and technology, culture and other fields, and serve the economic and social development of all countries and regions along the "one belt and one road".

\section{THE "ONE BELT AND ONE ROAD" STRATEGY AND COLLEGE ENGLISH EDUCATION}

Compound talents with innovation and entrepreneurship awareness usually need to have rich knowledge reserve, good humanistic background and scientific literacy, open thinking mode and the spirit of brave exploration, criticism and query, as well as the ability to analyse and solve problems independently. General education emphasizes 
that the educatee should be regarded as a complete and subjective person to give a comprehensive education and pay attention to the harmonious development of human life, morality, emotion and reason, which is in line with the requirements of Marx's theory of human's comprehensive development. College English, as a public basic course for all majors in the University, should give full play to its unique advantages. Through classroom "teaching, we can help students understand English language and culture, and make them use their English skills and knowledge flexibly. Only in this way can we make a positive and independent judgment, which is beneficial to the innovation in the actual study and work in the future." [1] The connotation of foreign language innovative talents consists of innovative knowledge, innovative ability, innovative personality and innovative quality. It is an important task for foreign language education to cultivate "foreign language compound talents". Since college English classroom teaching time is concentrated in grade one or two, it is an important stage for the formation of College Students' world outlook, outlook on life and values, and there are many English classes, especially grade one, 5 class hours per week, which provides more opportunities for College English teachers to contact with students, directly participate in college students' employment guidance and help them establish a correct employment concept. In addition, the teaching content of English course includes language teaching and the cultivation of cross-cultural communication ability. Students can not only acquire language, but also accept the humanistic cultivation of ideology, will and character.

\section{AN ANALYSIS OF THE CURRENT SITUATION OF IDEOLOGICAL AND POLITICAL EDUCATION IN ENGLISH TEACHING}

At present, in English teaching, teachers pay attention to students' mastery of knowledge, neglect their professional quality education, and lack of innovation in teaching methods; the existing traditional college English teaching mode lacks ideological and political education, which is also concentrated in party and League activities, mainly relying on Ideological and political teachers and counselors, which can not meet the requirements of talent training; in addition, college students learn English Language has a strong utilitarian, mainly for postgraduate entrance examination, examination, employment and passing grade, which leads to the lack of attention to the integration of cultural knowledge in learning, the neglect of the cultural nature of language itself, the disconnection between classroom teaching and ideological and political education, resulting in some students can not treat western culture critically, and teachers can not measure the impact of foreign culture on students in the teaching process. [3]

\section{THE DESIGN OF THE TEACHING PLAN OF IDEOLOGICAL AND POLITICAL EDUCATION IN COLLEGE ENGLISH}

In College English classroom teaching, it is feasible to carry out targeted teaching programs, integrate ideological and political education elements into the classroom, carry out ideological and political education for students, and use basic theoretical knowledge and practical practice in College English ideological and political education teaching. Based on the analysis of the current situation of College Students' Ideological and moral education, this paper takes the ideological and political education of College English as the ultimate goal of learning: first, to enable students to have the ability of independent learning and advanced ideological guidance; second, to enable students to have the will to develop morally, intellectually, physically and aesthetically in an all-round way, and to combine learning with ideological and moral cultivation, so as to develop their own good habits and correct consciousness of life Third, to make students improve their aesthetic taste and inner self-cultivation, pay attention to humanistic spirit, discover the beauty of art and show their personality charm; fourth, to improve students' sense of social responsibility, with a strong sense of historical mission, strengthen our position in the cultural society to carry forward our cultural tradition, which is more conducive to cross-cultural exchanges between countries. In English teaching and ideological and political education, we should not only discuss the theoretical point of view, but also closely integrate with the reality. In most college English teaching, teachers arrange students to have interactive communication before class. Everyone expresses their opinions and shares some interesting stories with their classmates. Through this small link, students' oral expression ability can be trained. Teachers can also guide students to pay close attention to news and make full use of Internet media to pay close attention to the new events around them.

Curriculum evaluation is a guide. English curriculum evaluation should not only pay attention to the result evaluation, but also pay attention to the process evaluation. The existing evaluation system only takes the paper score at the end of the period as $90 \%$ of the total evaluation score, which is inevitably biased. It overemphasizes the result evaluation and ignores the process evaluation, which virtually strikes the students' learning enthusiasm and affects the cultivation of their thinking ability. Therefore, the proportion of process evaluation should be increased to form a multi-dimensional evaluation system. Pay attention to students' classroom performance, evaluate students with rich classroom activities such as personal presentation, group discussion, debate and speech, writing research report, etc. There is no unified and standardized answer to this kind of activities, which is conducive to the cultivation of students' thinking ability and creativity, and to the stimulation of students' thinking activity. 
[8] Gong Ping, Tian Yuan. An analysis of Ideological and political approaches to college English curriculum [J]. Intelligence, 2020 (02): 14

[9] Zhang Yuqing, Qu Yuqing. On the teaching mode of "Ideological and Political Courses" in College English based on Hybrid Teaching [J]. Overseas English, 2020 (02): 174-175

\section{REFERENCES}

[1] Lei chaozi. Thoughts on promoting innovation and Entrepreneurship of college students [J]. China higher education, 2017, (z2): 57-60

[2] Liu Weidong, Lei Yi. Research on the construction of innovation and entrepreneurship curriculum system based on the whole process of talent training $[\mathrm{J}]$.

Journal of National Education Administration College, 2017, (08): 8-14

[3] Zhu Shuqin, Chen Zhen. Application of innovative strategies in Ideological and political education in universities [J]. Education modernization, 2017, 4 (27): 179-180

[4] Li Jie. On the integration of Ideological and political education of college students and English Classroom Teaching [J]. Science and technology information, 2017, 15 (02): 143-144

[5] Wang Yue. In the intelligent teaching of College English Ideological and Political Education -- Taking Guangxi Normal University as an example Journal of Danjiang University of education, 2019 (4): 52-53

[6] [1] Bian Yunfei, di Tianxiu. From "curriculum ideological and political" Problems in College English teaching and their solutions Methods [J]. Curriculum education research, 2019 (14): 119

[7] Jia Xiaolin. An analysis of the implementation path of College English curriculum ideological and Political Education [J]. Modern communication, 2020 (02): 175 $+174$ 